\title{
How Do We Understand Organizational Identity Effect?
}

\author{
Hidenori SATO ${ }^{\text {a) }}$
}

\begin{abstract}
Organizational identity is a set of characteristics that reflect an organization's distinctiveness. The solution to the issues of organizational identity requires an individual and specific comprehension. Therefore, cross-sectional quantitative research for a pre-established category established by the researcher was difficult to perform. As a result, until now, the mainstream organizational identity studies have been qualitative rather than quantitative. However, while one aspect of organizational identity studies is to solve the question of organizational identity itself, another aspect is to solve the question of its impact on the organization. Qualitative methods may be appropriate to solve the question of organizational identity itself, but quantitative methods are better suited to solve the question regarding its organizational impact. In other words, it is possible to utilize qualitative methods to comprehend an organization's identity while using quantitative methods, for example, to measure the organizational identification of its members and conflicts that arise from the differences in directivity among its members. Research utilizing quantitative methods of this type may increase in the future.
\end{abstract}

Keywords: organizational identity, research methods

a) Faculty of International Social Science, Yokohama National University, 79-4 Tokiwadai, Hodogaya-ku, Yokohama, Japan, hidesato@ynu.ac.jp

A version of this paper was presented at the ABAS Conference 2013 Autumn (Sato, 2013). 


\section{Introduction}

This paper will suggest some possibilities regarding future empirical studies on organizational identity. According to Albert and Whetten (1985, p. 265), organizational identity refers to organizational characteristics that are: i) central, ii) distinctive, and iii) enduring. Albert and Whetten (1985) introduced this concept, and Dutton and Dukerich (1991) initiated empirical studies. Since then, a number of studies ${ }^{1}$ have followed.

In recent years, research to further the understanding of the concept of organizational identity and its impact on the organization has progressed. At the same time, discussions have emerged regarding how to comprehend organizational identity empirically. ${ }^{2}$

\section{A Review of Research Method in Organizational Identity Studies}

The following is a review of discussions to date regarding methodologies employed in organizational identity research. Ravasi and van Rekom (2003) have identified the following characteristics regarding the methods employed in organizational identity studies: First, organizational identities are concerned either with claims made by a member(s) of an organization or with a narrative about the organization. Therefore, data used for empirical studies tend to rely on information collected from insiders with intimate knowledge of the organization in question. Archival material also provides a source of information for empirical studies. The collected data are often used for developing a descriptive argument rather than for measurement purposes. Thus, the study is qualitative in nature.

1 For example, refer to Gioia, Patvardhan, Hamilton, and Corley (2013).

2 As research progressed, the focus and method of research has evolved much like in other fields of research. For example, see Kuwashima (2012, 2013), and Kuwashima and Fujimoto (2013). 
The above can be confirmed in research concerning the methodologies employed in organizational identity studies by van Rekom and van Riel (2000), Oliver and Roos (2007), and Ravasi and Canato (2013).

Van Rekom and van Riel (2000) examined 13 studies and found that two of them were survey-type, eight research-based on an open-ended questionnaire, and three a combination of the two.

Of the 22 empirical studies examined by Oliver and Roos (2007), three represented quantitative methods alone using a large sample survey, two represented a combination of both qualitative and quantitative methods, and the remainder were qualitative in nature using such means as interviews, archival material, and data based on participant observations.

Ravasi and Canato (2013) reviewed the methodologies employed in empirical studies on the subject of organizational identities that appeared in top-tier management journals between 1985 and 2011 . $^{3}$ They examined 33 empirical studies and classified them into five research methods, i.e., survey, extended metaphor, grounded theory, ethnography, and narrative analysis. Of the five methods, survey and extended metaphor represented quantitative methods, while grounded theory, ethnography, and narrative analysis represented qualitative methods.

Of the 33 research that they reviewed, 5 employed quantitative methods, 27 employed qualitative methods, and 1 used a combination of the two.

3 Ravasi and Canato (2013) gave the following publications as examples of top-tier management journals: Academy of Management Journal, Administrative Science Quarterly, British Journal of Management, Human Relations, Journal of Management, Journal of Management Studies, Journal of Organizational Behavior, Organization Science, Organization Studies, Strategic Management Journal, and Strategic Organization. However, in their actual thesis, none of the research appearing in Journal of Management, Journal of Organizational Behavior, and Strategic Management Journal was cited. 
Table 1. Research method in organizational identity studies

\begin{tabular}{|c|c|c|}
\hline & Method & Data source \\
\hline \multirow[t]{2}{*}{ Quantitative } & Survey & $\begin{array}{l}\text { - Preliminary interview or focus } \\
\text { group with representative } \\
\text { sample } \\
\text {-Survey }\end{array}$ \\
\hline & $\begin{array}{l}\text { Extended } \\
\text { metaphor }\end{array}$ & $\begin{array}{l}\text {-Interview with key informants } \\
\text { - Focus group } \\
\text { - Survey }\end{array}$ \\
\hline \multirow[t]{3}{*}{ Qualitative } & $\begin{array}{l}\text { Grounded } \\
\text { theory }\end{array}$ & $\begin{array}{l}\text { - Interviews } \\
\text { - Archival data }\end{array}$ \\
\hline & Ethnography & $\begin{array}{l}\text { - Interviews } \\
\text { - Archival data } \\
\text { - Observation }\end{array}$ \\
\hline & $\begin{array}{l}\text { Narrative } \\
\text { analysis }\end{array}$ & $\begin{array}{l}\text { - Oral and written texts } \\
\text { - Archival data } \\
\text { - Organizational statement }\end{array}$ \\
\hline
\end{tabular}

Source: Based on Ravasi and Canato (2013), p. 189, Table1 and Table2

Although Ravasi and Canato's (2013) reviews of past studies on the subject extended only up to 2011, the basic trend thereafter remains the same. Nine empirical studies were published between 2012 and 2013 using the same selection standards used by Ravasi and Canato (2013). Of these studies, only two publications used quantitative methods, i.e., Cable, Gino and Staats (2013) and Hsu and Elsbach (2013).

Moreover, of the two publications, Hsu and Elsbach (2013) employed a combination of both quantitative and qualitative methods.

Elstak (2008) indicated that the lack of quantitative research was problematic, arguing that organizational identity studies was a 
Table 2. Empirical research in organizational identity studies

\begin{tabular}{lccc}
\hline Journal title & $\begin{array}{c}\text { Number of } \\
\text { articles in Ravasi } \\
\text { and Canato } \\
(2013)\end{array}$ & $\begin{array}{c}\text { Number of } \\
\text { articles in 2012 } \\
\text { and 2013 }\end{array}$ & Total \\
\hline $\begin{array}{l}\text { Academy of } \\
\text { Management Journal }\end{array}$ & 3 & 2 & 5 \\
\hline $\begin{array}{l}\text { Administrative Science } \\
\text { Quarterly }\end{array}$ & $8(2)$ & $1(1)$ & $9(3)$ \\
\hline $\begin{array}{l}\text { British Journal of } \\
\text { Management }\end{array}$ & 4 & 0 & 4 \\
\hline $\begin{array}{l}\text { Human Relations } \\
\text { Journal of Management }\end{array}$ & 2 & 1 & 3 \\
\hline Organies & $8(3)$ & 0 & 4 \\
\hline Organization Studies & 3 & 2 & $11(4)$ \\
\hline Strategic Organization & 1 & 0 & 1 \\
\hline
\end{tabular}

Note: Number of quantitative research is shown in parentheses.

maturing field of research and that researchers needed to develop measurement methodologies in line with development of its theoretical aspects.

In this paper, the author inspects why qualitative research has been so predominant and how quantitative research can be better utilized.

\section{Qualitative Research in Organizational Identity Studies}

Dutton and Dukerich (1991) released empirical studies during the initial stages of organizational identity using qualitative methods. They used data from open-ended interviews, archival material gathered within the organization, and articles found in newspapers 
and magazines.

In the years that followed, various methods were used to publish a number of additional qualitative studies. Ravasi and Schultz (2006) used data collected from semi-structured interviews, identity seminars, house magazines and other internal communication tools, annual reports and external communication tools, corporate histories, and other archival material. The method of data analysis is based on the grounded theory (Glaser \& Straus, 1967).

Nag, Corley, and Gioia (2007) analyzed data using the grounded theory approach. In this study, they employed data collected from interviews as well as observation and archival sources.

Clark, Gioia, Ketchen, and Thomas (2010) used data collected from semi-structured interviews, participant observations, and archival data; grounded theory was again employed as a method for analysis.

Studies using methods of analysis other than grounded theory include research by Humphreys and Brown (2002), Ybema (2010), Cheim (2005), and Sillince and Brown (2009). They used similar sources for their data collection. For instance, Humphreys and Brown (2002) collected data from 42 semi-structured interviews, informal interviews, and observations, as well as a vast range of documentation.

In many cases, organizational identity studies have focused on the problem of whether an organization indeed possessed an organizational identity. It was therefore necessary to conduct qualitative research in order to determine each organization's unique identity.

\section{Quantitative Research in Organizational Identity Studies}

Ravasi and Canato (2013) cited five studies where quantitative methods were employed. However, these studies did not necessarily use quantitative methods to analyze the contents of the 
organizational identity.

Bartel (2001) identified 23 items representing organizational identity factors using semi-structured interviews including pre-determined questions such as, "What adjectives would you use to describe...?" and "What are some key values at...?" Respondents were asked to rate their answers regarding the applicability to their organization using a seven-point scale.

The same is applicable to Dukerich, Golden, and Shortell (2002). In this study, a focus group specified 37 organizational identity traits in advance.

Foreman and Whetten (2002) focused on what happens when there is a conflict among multiple organizational identities. The method they used was to hold discussions among a focus group regarding two conflicting organizational identities, normative and utilitarian, and have the focus group select five items from each camp that best represent their organizational identity.

Martins (2005) did not comment on the contents of each individual identity; rather, he dealt with the strength and the external orientation of organizational identities.

Voss, Cable, and Voss (2006) used the five dimensions-artistic, pro-social, market, achievement, and financial-derived from prior research conducted on the same nonprofit professional theaters.

Cable, Gino, and Staats (2013) used experiments as their methodology. They compared newcomer's socialization process that focused on organizational identity with the process that focused on personal identity. However, they did not specifically determine the organizational identity.

Hsu and Elsbach (2013) described an organizational identity qualitatively in the first stages of their research and went on to employ quantitative analysis in areas such as its relationship with organizational identification in the second stages of their research.

As shown above, while there were studies that employed 
quantitative methods, for the most part, qualitative methods were also used initially. As quantitative methods alone were insufficient to comprehend the organizational identity of an individual organization, they needed to be combined with qualitative methods.

\section{Conclusion}

This paper discussed research methodologies employed in organizational identity studies and confirmed that qualitative methods were compatible as a method of analysis. This is evident by the fact that an exceptionally high percentage of organizational identity studies have produced qualitative research. Therefore, qualitative methods may continue to constitute the main research approach in this field of study.

Additionally, this paper has suggested the possibility of employing quantitative research in organizational identity studies; that is, the combination of qualitative methods with quantitative methods.

Given the fact that organizational identity is the discovery of an organization's distinctiveness, the concept itself inherently necessitates an individual and specific comprehension of organizational identity. Therefore, a measurement methodology based on predetermined categories established by the researcher does not sufficiently solve the question of organizational identity. Cross-sectional quantitative research alone is insufficient and must be combined with qualitative research.

There are two aspects to the research of organizational identity; one is to determine the organization's identity and the other is to understand how organizational identities affect organizations. Qualitative methods are better suited for solving the first question regarding the organization's identity while quantitative methods are effective in solving the second question regarding its impact on the organization. 
In conclusion, the author believes that future studies will increasingly employ quantitative methods to measure, for instance, the impact of conflicts about the differences in how members perceive their organizational identity and the directivity among the organization members while employing qualitative methods to comprehend the organization's identity itself. ${ }^{4}$

\section{References}

Albert, S., \& Whetten, D. A. (1985). Organizational identity. Research in Organizational Behavior, 7, 263-295.

Bartel, C. A. (2001). Social comparisons in boundary-spanning work: Effects of community outreach on members' organizational identity and identification. Administrative Science Quarterly, 46(3), 379-413.

Cable, D. M., Gino, F., \& Staats, B. R. (2013). Breaking them in or eliciting their best? Reframing socialization around newcomers' authentic self-expression. Administrative Science Quarterly, 58(1), 1-36.

Cheim, S. (2005). The continuity-change duality in narrative texts of organizational identity. Journal of Management Studies, 42(3), 567-593.

Clark, S. M., Gioia, D. A., Ketchen, D. J., Jr., \& Thomas, J. B. (2010). Transitional identity as a facilitator of organizational identity change during a merger. Administrative Science Quarterly, 55(3), 397-438.

Dukerich, J. M., Golden, B. R., \& Shortell, S. M. (2002). Beauty is in the eye of the beholder: The impact of organizational identification, identity, and image on the cooperative behaviors of physicians. Administrative Science Quarterly, 47(3), 507-533.

Dutton, J. E., \& Dukerich, J. M. (1991). Keeping an eye on the mirror: Image and identity in organizational adaptation. Academy of Management Journal, 34(3), 517-554.

4 However, the results of an analysis could also change in this case depending on the degree of specificity and uniqueness of the organizational identity. See Sato (2014) for details. 
Elstak, M. N. (2008). The paradox of the organizational identity field. Corporate Reputation Review, 11(3), 277-281.

Foreman, P., \& Whetten, D. A. (2002). Members' identification with multiple-identity organizations. Organization Science, 13(6), 618-635.

Gioia, D. A., Patvardhan, S. D., Hamilton, A. L., \& Corley, K. G. (2013). Organizational identity formation and change. Academy of Management Annals, 7, 123-193.

Glaser, B. G., \& Strauss, A. L. (1967). The discovery of grounded theory. New York, NY: Aldine.

Hsu, G., \& Elsbach, K. D. (2013). Explaining variations in organizational identity categorization. Organization Science, 24(4), 996-1013.

Humphreys, M., \& Brown, A. D. (2002). Narratives of organizational identity and identification: A case study of hegemony and resistance. Organization Studies, 23(3), 421-447.

Kuwashima, K. (2012). Product development research cycle: A historical review 1960s-1980s. Annals of Business Administrative Science, 11, 11-23. doi: 10.7880/abas.11.11

Kuwashima, K. (2013). Followers of Harvard Study: A review of product development research 1990s-2000s. Annals of Business Administrative Science, 12, 31-44. doi: 10.7880/abas.12.31

Kuwashima, K., \& Fujimoto, T. (2013). Performance measurement in product development research: A literature review. Annals of Business Administrative Science, 12, 213-223. doi: 10.7880/abas.12.213

Martins, L. L. (2005). A model of the effects of reputational rankings on organizational change. Organization Science, 16(6), 701-720.

Nag, R., Corley, K. G., \& Gioia, D. A. (2007). The intersection of organizational identity, knowledge, and practice: Attempting strategic change via knowledge grafting. Academy of Management Journal, 50(4), 821-847.

Oliver, D., \& Roos, J. (2007). Beyond text: Constructing organizational identity multimodally. British Journal of Management, 18(4), 342-358.

Ravasi, D., \& Canato, A. (2013). How do I know who you think you are? A review of research methods on organizational identity. International Journal of Management Reviews, 15(2), 185-204.

Ravasi, D., \& Schultz, M. (2006). Responding to organizational identity 
threats: Exploring the role of organizational culture. Academy of Management Journal, 49(3), 433-458.

Ravasi, D., \& van Rekom, J. (2003). Key issues in organizational identity and identification theory. Corporate Reputation Review, 6(2), 118-132.

Sato, H. (2013, November). How do we understand organizational identity? Paper presented at ABAS Conference 2013 Autumn, University of Tokyo, Japan.

Sato, H. (2014). How to choose an appropriate dress?: An influence of change in organizational identity. Annals of Business Administrative Science, 13, 141-151. doi: 10.7880/abas.13.141

Sillince, A. A., \& Brown, A. D. (2009). Multiple organizational identities and legitimacy: The rhetoric of police websites. Human Relations, 62(12), 1829-1856.

van Rekom, J., \& van Riel, C. B. M. (2000). Operational measures of organizational identity: A review of existing methods. Corporate Reputation Review, 3(4), 334-350.

Voss, Z. G., Cable, D. M., \& Voss, G. B. (2006). Organizational identity and firm performance: What happens when leaders disagree about "Who we are?" Organization Science, 17(6), 741-755.

Ybema, S. (2010). Talk of change: Temporal contrasts and collective identities. Organization Studies, 31(4), 481-503. 